\title{
Peter Osterried
}

Ruhr-University Bochum, Germany

ORCID: https://orcid.org/oooo-0oo3-4819-2980

\section{Beaches as borders and Beaches overcoming Borders: An Appeal of the Humanities for more Humanity}

\section{$\approx$ Resumen}

Este artículo investiga el potencial cultural de la playa como espacio concreto, cargado de significado y, en última instancia, como emplazamiento metafórico de una visión idealista. En conjunción con la muy actual dimensión de las playas como fronteras para los fugitivos, el artículo debate sobre la relevancia social de las humanidades, prestando particular atención al papel que desempeñan los estudios culturales. Para ello se examinarán diversos productos culturales, tanto canónicos como procedentes de lo que genéricamente se entiende como cultura popular y, por lo tanto, expuestos a mayores audiencias. En todos ellos se examinará cómo se centran en el motivo de la playa. En la discusión se argumentará que los estudios culturales tienen la capacidad de contribuir significativamente a debates de tipo moral y, más concretamente, al que gira sobre qué actitudes pueden considerarse éticamente aceptables en las sociedades occidentales. Así, y al contrario de lo que sucede en el seno de otras disciplinas académicas, los estudios culturales están íntimamente relacionados con la realidad y la política, emergiendo por lo tanto como una disciplina ajena a la torre de marfil que es el mundo académico, ya que aborda la vida y, lo que es aun más importante, puede tener un impacto práctico sobre la misma.

\section{Palabras clave:}

playa; estudios culturales; metáfora; humanidades; relevancia

\section{$\approx$ Abstract}

This article investigates the cultural potential of the beach as a concrete place, a meaning-laden space, and finally as a metaphorical setting of idealistic vision. In conjunction with the politically heated dimension of beaches as borders to fugitives, the relevance that the humanities play in society is discussed placing particular emphasis on the role of cultural studies. Quite a number of cultural products both from the canon of high culture and from popular culture reaching wider audiences will be examined in the way they centre on the pivot of the beach. Cultural studies, it will turn out, is able to significantly contribute to discussions on morals and, beyond that, to the question of what attitudes in Western societies can be considered ethically acceptable. Thus, in contrast to many other academic disciplines, cultural studies is closely linked to reality and politics so that it is a discipline away from the ivory tower of academia because it deals with life and, most importantly, can have a practical impact on it. 
ot only in Spanish Academia, but in many European countries, modern cultural studies have had a rather short history, compared to the case of Britain, where the cradle of modern cultural studies can be clearly located at the Centre for Contemporary Cultural Studies at the University of Birmingham, founded in I964 (Kramer 1997, 44; Storey 2009, 38). In contrast to established philosophical and philological disciplines, the early beginnings of cultural studies cannot be located more than some fifty years ago, that is still very recently within the long history of heuristics. One need not be an insider in the privileged academic circles to guess what consequences cultural critics still have and invariably have had to face as a result of a discipline that can still be called new. Instead of being praised for innovative approaches and views, the necessity of self-justification seems to be the cultural critic's daily bread and butter, as soon as some philosophers, literary critics and other well-furred notabilities decide to invite cultural critics into their circles. Such a situation proves to be ironic and stunning for one main reason.

The image of the ivory tower (VidmarHorvat 2012) Academia has been compared to is perhaps especially applicable to research within the humanities as there is the widespread perception that what contemporary humanist scholars do, namely write and discuss, does not really produce tangible results indispensable to life. A little anecdote might easily give food to that blame. When I was a little boy, my mother, an excellent grammar-school teacher of English and French, then still alive (I lost her to cancer when I was sixteen), once said to one of her colleagues specializing in philosophy: "What the hell is the point in all philosophy and philology? It's nonsense. What happens if philosophy professors do not go to university for four weeks? Nothing! What, however, is going to happen if the garbage collectors are on strike? There'll be pure danger for the rats are taking over!" The philosophy teacher was not amused. To cut it short: The first argument against the relevance of the humanities - our relevance as humanities scholars - lies in that it / we are not necessary for practical survival: We do not provide food, we do not produce anything else but meaning that, to put it in Derridean terms (Kramer 1997, I06), is quickly delayed. Last and perhaps most importantly, we do not provide a cure for illness let alone medical care.

Needless to say, there are buts against this. Normally, the classic, big, and ever-adduced but is the psychological cure and care that we provide. This idealistic view of philological activity, based on the understanding that it influences the individual's moral attitudes, paves the way for psychological catharsis. Let us refer to Friedrich Schiller and his famous words from his letter 24 here: "Man in his physical state merely suffers the dominion of nature; he emancipates himself from this dominion in the aesthetic state, and he acquires mastery over it in the moral" (Schiller 1967, I7I). Despite the risk of man's reason running for materialism and sensuality only (something alluded to already by Schiller himself and later on fully discussed by the Frankfurt School), it could be argued that many humanities scholars still believe in this dream: through the discourse on the beautiful one makes oneself and one's readers viz. students more sensitive and empathetic towards the fellow men in society.

Now it is not my mother being provocative, but her son, for, to all my knowledge and experience, I regard the joint venture of aesthetics and ethics as a cathartic illusion. If it were true, everybody in Academia would only have known empathetic, likeable and charitable people working in the humanities.

The guiding question of my article is the consequence of the above reflections. If, unlike the so-called "sciences", the humanities cannot claim to either contribute to the survival of fellow human beings in a practical way or have a clearly observable positive impact on social morality, what is their relevance after all then rooted in? In what follows I shall attempt to provide an answer to this question, although first the scope of this article needs to be narrowed down. Thus, the question will be tackled by focusing on one key metaphor, the beach, and its multi-faceted representation in filmic, artistic and literary discourse.

\section{The beach as a concrete place of action}

In order to understand the cultural tenors that the concept of a beach evokes, it might prove sensible to first consider the beach as a specific, and so not yet figuratively tinged place. This is in no small part due to the fact that, after the great many heartbreaking pictures of fugitives on the Mediterranean that have widely circulated over the last few years, the beach has become a mediated setting of political interest, action and (deplorably) even war.

The beach especially works as a place of hope and survival, away from the dangers of the sea and away from the home country of the fugitives. Undoubtedly, already before the recent times of mass migrations, the beach was practised widely and differently by people. To any traveller, from antiquity to the present time, the sea has invariably aroused the desire to 'sail away'. This is in fact the tile of an enormously popular song by Enya (taken from her I988 album Watermark and also known as "Orinoco Flow") often played when a cruise ship leaves port, taking passengers onboard on to their next destination and conjuring up their longing for both freedom and adventure. As opposed to this moment, there is the modern fisherman's work that has become ever more difficult due to new technologies ruining the old image of the fisherman arriving at sunset with the catch of the day at a small village by the seaside; today, the beach is still the place where those few fishermen that have not given up their profession can sell the seafood in order to make an often deplorably low living.

In light of the three above examples (fugitives, travellers, fishermen), and the different connotations they stand for, it is clear that the beach as a place, once looked at, is according to de Certeau (I988), a space per se, no longer objective, but highly subjective and meaning-laden. What the connotations of the three examples above suggest is that the beach as a space is based on multiple binary opposites, all of them defined by the notion of the borderline. Thus, the beach represents the borderline between many a phenomenon: the earth and the sea, civilization and nature, agriculture and fishing, duty and adventure, safety and danger, but also imprisonment and freedom. Such contrastive elements can be seen in numerous cultural representations of the beach. De Certeau's concept of space will prove essential in the forthcoming discussion, as it clearly points to thehigh metaphorical potential of places.

A headstone of high culture with the beach as its pivot: Mathew Arnold

Taking a cursory look at beach discourses proves a rewarding experience in that it naturally involves retracing the 
$\sim$ development of cultural studies in general. A modern view of culture is holistic; as such, it necessarily includes the "popular". To put it in a nutshell: modern cultural studies is centred around "lived cultures and practices" (Storey 2009, I4). Needless to say, this liberal-minded open-heartedness stands in stark contrast to elitist Mathew Arnold, whose notorious concept of culture as the "best that has been thought and said in the world" (Arnold I960, 6) led him to view popular culture as anarchy (Storey 2009, I4).

For the purposes of this article, it will be interesting to observe how beach discourses develop from canonical literary texts to films with a broader audience, and to stress it right away, how the former and the latter share more features than one might at first expect.

Mathew Arnold's famous poem "Dover Beach" (I867) is directly and indirectly based on oppositions, divisions, and borders. These oppositions pivot around the beach on the one hand, accompanied, on the other hand, by the music of the backward and forward of the waves breaking upon the shore. The speakerpoet calls upon his love to "listen" to the sea "calm tonight" under "the moon [...] fair" (Arnold I980, II). The poem, notwithstanding its solemn, ode-like tone, does not conjure up peaceful romantic notes in the vein of a post-Romantic picturesque, though. Instead, the text features the somewhat dark romanticism of loss, quite in the same style as many a Caspar David Friedrich canvas rooting in the sublime: Seestück bei Mondschein / Sea Piece under the moon $(1830 / 35)$ is a fine yet not very well-known example of Caspar David Friedrich's rich oeuvre.

Not astonishingly, and yet not less artfully, the gloomy darkness veiling the bright cliffs of Dover varies as well as it stems from some of the dichotomies detected above as characteristic of the popular views of the beach. In Arnold, the motherland identified with the "cliffs of England" (Dover is a metonymy standing for the whole of England) is no safe home any longer for the poet fears "ignorant armies" and "a darkling plain". The "sea of faith" inspiring spherical associations was heard in the past, and the poet's present despair is so frantic that it casts a shadow on the Hellenistic time represented by Sophocles who, as Arnold imagines, already heard the melancholic sound of the waves on the Aegean, bringing "into his mind the turbid ebb and flow of human misery".

The beach as a space of border can also be seen in many a work of more popular art, for instance in such famous plays like $A$ Streetcar Named Desire.

The beach as a space of border in Tennessee Williams: a milestone of American drama

Without doubt, Tennessee Williams' breakthrough play A Streetcar Named Desire occupies a place of honour in the canon of high American post-war drama. On Broadway, it premiered in 1947 to be performed thereupon 855 times en suite (Geisen 1988, I79). This fact already alludes to the stunning effect the play has exerted on wide audiences right from the start. Hence, it comes as no surprise that the play's reception history marks the development from originally one of the finest plays of the 2oth century with a notably high intellectual potential to one that has inspired - up to the present day - not only film directors like Elia Kazan, but also more recently musical, opera and ballet composers, singers, and dancers. As I see it, the sea and thus implicitly the beach metaphor underlying the protagonist Blanche Dubois' last monologue, contributes to the play's impressive popularity. Also sung as an aria by Renée Fleming in the opera production from 1995 (composed by André Previn), that very speech seems to have hit a nerve.

At this point, an interim conclusion can be reached. The examples hitherto reviewed provide evidence of high literature turn the beach into a space idealistically bridging borders. The literary difficulty and subtlety of the examples suggests that only the finest language mastery will be able to produce such an effect.

The question that I wish to turn to in what remains of my article lies in finding out whether the beach might become a more positive space, namely one where borders are no more in the foreground but where the gap between a here and there, and a now and then, can somehow be bridged.

\section{The beach as a space of fusion}

It is not only from our holiday experiences at the seaside but also from the fine arts that we know that sky, beach, and land can become one as in many William Turner paintings that work out a Romanticism of harmony by focusing on the picturesque, so different from the (Gothic) sublime in Caspar David Friedrich. Turner's Calais Sands at low water (I830), for example, avoids a clear separation between fore-, middle- and background. Despite the easily recognizable fisherwomen gathering bait for the fishing of the coming day, middle and background, beach at low water and sky are so near each other that the viewer is unable to say

10 the conventionalized view of the beach as the border between a here and now as opposed to a there and then, both in the individual's concrete experiences of the beach as a real place as well as in representations provided by exemplary cultural products.

$2^{\circ}$ the fact that the aforementioned concept of the beach as a dichotomous space characterizes both cultural products from the high culture-canon as well as cultural products that have reached wider audiences and can thus be called more popular.

exactly where the horizon begins. Thus seen, the beach becomes a place of fusion.

The potential of this blending has largely inspired literature and many other cultural forms so that the following question automatically results from the preceding observations: Why is this view of the beach as a space of fusion so captivating that it has become, perhaps no less than the beach as a space of border, a topos especially in modernity and postmodernity (as will soon be seen e.g. in Thomas Mann, Ingeborg Bachmann and the recent film Moonlight (2016, dir. Berry Jenkins)?

The reason is that the eye, like language, if it is most impressed, tends to bridge gaps, between existent and non-existent phenomena or, as Kemp rightly puts it by stressing Foucault's words: "Within language, what cannot be said is said" (Kemp 2013, 153). Two examples from modernist literature clarify the idealistic potential of the beach in that the creation of the space helps to say what cannot be said - very much in contrast to Ludwig Wittgenstein's notorious rule Whereof one cannot speak, thereof one must be 
$\sim$ silent. Admittedly, thinking might go beyond the grasp of human language. However, through the metaphorical use of spaces, the impossible can be turned into something possible.

In Thomas Mann's novella Death in Venice (I9I2), the beaches of Venice's Lido appear as a fusion of earthly constraints and heavenly Platonic spheres: Gustav Aschenbach, in his mortal hour, once more contemplates the boy Tadzio, whom he has fallen in love with, and now, it is no more the lust for the boy's body that appeals to him. But when he sees him one last time on the beach, amidst the low waters, the Platonic idea of beauty finally becomes little known. Before, it was the body-centred copy of the beautiful that Aschenbach had tragically and erotically fallen in love with. When Tadzio raises his hand towards dying Aschenbach, the novella comes to an end as follows:

The metamorphosis from terrestrial to spiritual insight in dying would go beyond the grasp of language, even beyond the language mastery of a writer like Thomas Mann, if the scene were not laid at the beach. Author and reader are taken towards remote

Ihm [Aschenbach] war aber, als ob der bleiche und liebliche Psychagog [Tadzio] dort draußen ihm lächle, ihm winke: als ob er, die Hand aus der Hüfte lösend, hinausdeute, voranschwebe ins VerheißungsvollUngeheure. Und, wie so oft, machte er sich auf, ihm zu folgen. (Mann 2007, 138)

[It seemed to him [to Aschenbach], however, as if the pale and lovely shepherd of souls [Tadzio] out there smiled at him, beckoning, as if he took his hand from his hip and pointed, indeed himself glided ahead into the looming immensity, full of promise and portent. And as he had so often before, Aschenbach got up to follow.] (Mann, transl. Chase 2006, 218)

spheres against the background of the wafts of mist engulfing Tadzio at the Lido, this being also the final image of Visconti's I977 congenial film adaptation. Showing the terrestrial beautiful (so near the Platonic ideal) as a bridge to the divine in the form of an intellectual gay tale indeed makes the piece a novella revolving around unheard events, just to allude to Goethe's famous definition of what is the main characteristic of a novella. The definition can be reread in Goethe's conversations with Johann Peter Eckermann: The narrative of a novella, according to Goethe, revolves around "an event ever unheard before"(Eckermann i960, I60, my translation).

The comparable space works as the poetic fundament to the poem "Böhmenliegt am Meer" (1964) that the great Austrian poet Ingeborg Bachmann considered her best, for it sums up what she does not believe in and for what she hopes for nonetheless. All human life comes from the sea, as Ingeborg Bachmann elaborates on in her modernist poem. In it, dystopian modern society finds an alternative in a surreal fusion when, all of a sudden, Bohemia, once imaginarily put by the sea, passes the test of ethic morality and becomes the place of amnesty by the sea.

The poem's central stanza is based on an ambiguity that only works in German for $z u$ Grundegehen does not only mean to die but might be metaphorically used for to find the origin of something:
I have tried to make clear the ambiguity of the sea's bottom ("zugrund") working like the fundament of all good life in Bachmann and "zugrundegerichtet" in the sense of to be forced

\author{
Zugrund - das heißt zum Meer, dort find ich Böhmen \\ wieder.
}

Zugrund gerichtet, wach ich ruhig auf. (Bachmann 2016, I7)

[Down - that means at the bottom of the sea, there I'll find Bohemia,

Down there, like from a grave, I awake in peace] (my translation).

to die (to be reborn thereupon) by resorting to the paraphrase "down there, like from a grave". This is, admittedly, only half as ingenious as Bachmann's pun; however, in contrast to a number of professional translations by native English speakers, it does at least convey the two German meanings. Consequently, the metaphorical use of the idealistic notion of the beach derives from this central stanza: Bohemia put by the sea turns dystopia into utopia, but into a utopia so forceful that it seems real to the poet-speaker. Once the fusion between land and sea has been created, the belief in the ideal origin of life can be grasped again.

At this point, let me come to a second interim conclusion: two literary examples from what is generally considered the canon of high literature turn the beach into a space idealistically bridging borders. The literary difficulty and subtlety of the examples suggests that only the finest language mastery will be able to produce such an effect.

However, this does not mean the creation of spaces of similarly idealistic fusion is to be excluded from (more) popular cultural products, although, to find this, one has to leave the art of writing and move on to cinema, the seventh (and certainly most popular, and yet not less artful) art.

By way of example, let us consider a film scene from the recent film Moonlight (2016, dir. Berry Jenkins), whose topic and storyline both work along postmodernist lines. Despite the cuts and pauses in the biography of the protagonist Chiron, the film's narrative (in four loosely connected chapters) is "animated along an axis of silence and quiet" (Gillespie 2017, 53). This stands in stark contrast to the upsetting topic of a cruel "black masculinity" (ibid.) story spiralling around a youth trying to gain the identity of a tough drug dealer despite his gay sexual inclination. In the world of criminal survival that he construes for himself, his gayness finds no place. Consequently, he is lonesome until, only at the very end of the film, he meets the student friend again who once was his one and only sexual experience in life. The Independent considered the moonlit scene on the beach in Miami "Io of the best sex scenes in film" (The Independent 2019), perhaps because sex is hardly shown, only indicated with the two young men timidly finding pleasure in mutual masturbation. It is important to note, however, that the scene's emotive power largely results from its location on the coast.

The beach is a half-safe setting: Only here can the one and only sexual encounter in Chiron's life take place for the brutal 
world away from the beach refuses him such joy and love. Fortunately, there is a ray of hope when the men, grown older, meet again, making up their mind to take up their friendship again.

\section{A common ground beyond beaches and borders}

I started this article by stating my doubts about the necessity and usefulness of the humanities. Such doubts still haunt me. I do not believe that our work can make the world a better place nor improve human morals. However, our work is a place that invites us to discuss topics of only alleged non-relevance. And it is not only academics that share in this discourse. There are still plenty of others who - closely or loosely - participate in the academic circles, and thus, the humanities form a space away from hardcore reality but still linked to it. The humanities themselves are like a beach between what is and what could or should be. Especially, and that ought to be spelt as clearly as possible, cultural studies, with its openness to consider all kinds of cultural products, canonical and otherwise, plays a crucial part here. Undoubtedly, a vivid appreciation and discussion of the great variety of cultural products is and will be able to open perspectives for a better living.
Of particular interest and weight is the consideration of projects that make canonical works like Beethoven's Symphony No.9 become an inspiring piece to new audiences. For example, the Lausanne Ballet cooperated with artists and laymen from all over the world dancing Maurice Béjart's version of Beethoven's Symphony No. 9 in Tokyo in 2015.

The Song of Joy joined by people of all races and forming circles of beauty is the ballet's final ideal. Through the vivid discussions it opens up, as I have endeavoured to show, cultural studies is able to, if not bring to fruition, at least approach the ideal of people living and cooperating in harmony together. From the choice of the cultural products we have taken into account, one might already guess what I would suggest to modern humanistic disciplines such as history, literary studies, and philosophy. They should not only invite cultural studies like a passive onlooker in their circles but have themselves inspired by them to remain fresh, up-to-date, and useful.

\section{$\approx$ Works Cited}

AGUIRRE, A. (dir.). 20i7. Dancing Beethoven. Berlin: Arsenal Film. DVD.

ARNOLD, Mathew. 1960. Culture and Anarchy. London: Cambridge University Press. I980. "Dover Beach." In Insight III. Analyses of English and American Poetry, edited by Reinhold Schiffer, Hermann J. Weiand, II. Frankfurt am Main: Hirschgraben.

BACHMANN, Ingeborg. 20ı6, "Böhmen liegt am Meer." In Ingeborg Bachmanns Winterreise nach Prag, edited by Hans Höller, Arturo Larcati, I7. München/Berlin: Piper.

DE CERTEAU, Michel. 1988. The Practice of Everyday Life. Berkeley: University of California Press.

ECKERMANN, Johann Peter. 1960. Gespräche mit Goethe in den letzten Jahren seines Lebens. Reutlingen: Bertelsmann.

ENYA. 1988. Orinoco Flow (Sail Away) from 'Watermark'. Enya. USA: Geffen.

FRIEDRICH, Caspar David. I830/I835.SeestückbeiMondschein, oil on canvas, 25 by 3I cm. Leipzig: Museum der Bildenden Künste.

GEISEN, Herbert. 1988. "Nachwort." In A Streetcar Named Desire, I79-197. Stuttgart: Reclam.

GILLESPIE, Michael Boyce. 2017. “One Step Ahead: A Conversation with Barry Jenkins.” Film Quarterly 70 (3): 55-62.

JENKINS, Barry (dir.). 20i6. Moonlight. New York: A24. DVD

KEMP, Jonathan. 2013. The Penetrated Male. New York: Punctum Books.

KRAMER, Jürgen. 1997. British Cultural Studies. München: Wilhelm Fink.

MANN, Thomas. 2006. Death in Venice and other Stories, translated and introduced by Jefferson S. Chase with a New Afterword by Martin Swales. New York: Signet Classics.

MANN, Thomas. 2007. Der Tod in Venedig. Frankfurt am Main: Fischer.

PREVIN, André. I995. A Streetcar Named Desire. USA: G Schirmer Inc. 
SCHILLER, Friedrich von. 1967. On the Aesthetic Education of Man: In a Series of Letters English and German Facing, edited and translated by Elizabeth M. Wilkinson and L.A. Willoughby. Oxford: Clarendon Press.

STOREY, John. 2009. Cultural Theory and Popular Culture. An Introduction. London: Pearson/Longman.

"The ro best sex scenes in film". The Independent. https://www.independent.co.uk/arts-entertainment/films/features/best-film-sex-scenesfilms-top-ro-movies-mulholland-drive-moonlight-gods-own-country-blue-valentine-a8541826.html (Accessed August 25, 2019).

TURNER, William. I830. Calais Sands at low water, oil on canvas, 73 by $107 \mathrm{~cm}$. Bury: Bury Art Museum.

VIDMARHORVAT, Ksenija. 20r2. "Sociology of Culture and Cultural Studies: Towards a Postsocialist Reconciliation." Revija Za Socioloiju 42 (2): II9-40.

VISCONTI, Luchino (dir.). I971. Death in Venice. Burbank, CA: Warner Bros. DVD.

WILLIAMS, Tennessee. 1988. A Streetcar Named Desire. Stuttgart: Reclam. CD. 